\title{
早期喉頭癌照射後頸部リンパ節再発例の検討
}

\author{
楯谷 智子・庄司 和彦・高北 晋一 \\ 鈴木 慎二・河田 恭孝・岸本 曜

\section{Cervical Lymph Node Recurrence after Curative Radiation Therapy in Early Laryngeal Cancers}

\author{
Tomoko Tateya, Kazuhiko Shoji, Shin-ichi Takagita, \\ Shinji Suzuki, Yasutaka Kawata and You Kishimoto \\ (Tenri Hospital)
}

\begin{abstract}
One hundred and thirty-three patients with early laryngeal cancer received curative radiation therapy at Tenri Hospital from 1983 to 2000 . Four patients (3\%) experienced cervical lymph node recurrence and had their primary tumor controlled. They underwent salvage treatment including neck dissection. Two of them later had local recurrence and underwent total laryngectomy, which was unsuccessful in one case. The others have been disease-free after salvage treatment. We conclude that cervical lymph nodes recurrence does not indicate total larygectomy at that time if the primary site is clinically disease-free.
\end{abstract}

Key words : curative radiation therapy, cervical lymph node recurrence, early laryngeal cancer

はじめに

早期喉頭癌放射線治療後の再発は局所再発が多く, そ の場合, 喉頭摘出によりサルベージが可能である.一方, 局所再発に比べて頻度は少ないが，放射線治療後に頸部 リンパ節再発をきたすことがある，局所再発と頸部リン パ節再発を同時に認めた場合，局所と頸部の両方にサル ベージ治療を行うことになるが, 局所再発を認めずに頸 部リンパ節再発した場合, 頸部リンパ節転移は初回治療 時すでに存在していたか, 喉頭に残存病変があってそれ が転移したという 2 つの可能性があるため，治療は頸部 に対してのみ行らのが適当なのかどらか疑問が残る。こ のように, 局所再発を認めずに頸部リンパ節再発をきた した症例について, サルベージ手術として喉頭全摘が必 要かどうかを含め, 治療と予後について述べている報告 はほとんどない。頸部リンパ節に再発した時点では，こ れが潜在的リンパ節転移が顕在化したものか, 喉頭の残 存病変の転移であるかは区別しがたいので, 当科では喉
頭を精査した上で頸部のみ治療し喉頭は経過観察してい た. 今回そのような症例の臨床像, 特に喉頭保存につき 検討したので報告する.

\section{対 象}

1983 年 1 月から 2000 年 3 月の間に当科で初回治療と して根治的放射線治療を行い, 2 年以上の経過観察を行っ た喉頭扁平上皮癌 I 期・II 期症例 133 例（男性 127 例, 女 性 6 例, 年齢 $37 \sim 83$ 歳, 平均年歯 65 歳, 平均経過観察 期間 6 年）を対象とした. I 期は 86 例，II 期は 47 例であ り, 発生部位は声門 112 例, 声門上 17 例, 声門下 4 例で あった (表 1). 臨床病期分類は頭頸部癌取り扱い規約改 訂第 3 版（2001 年 11 月）に従った。照射線量は I 期症 例，II 期症例とも，時期により $60 \sim 70 \mathrm{~Gy}$ の変遷があ るが (表 2), I 期症例の平均総線量は $64 \mathrm{~Gy}$, II 期症例は $68 \mathrm{~Gy}$ であった. また，この 133 例中 69 例には全身麻酔 下に直達喉頭鏡下レーザー手術を併用している. 
表 1 臨床病期と発生部位

\begin{tabular}{lrcr}
\hline \hline 発生部位 & I 期 & II 期 & 計 \\
\hline 声門 & 80 & 32 & 112 \\
声門上部 & 6 & 11 & 17 \\
声門下部 & & 4 & 4 \\
\hline \multicolumn{1}{c}{ 計 } & 86 & 47 & 133
\end{tabular}

表 2 当科における早期喉頭癌治療方針の変遷

\begin{tabular}{ll}
\hline \hline & 放射線治療総線量 \\
\hline 1987 年 12 月まで & $\mathrm{T} 1, \mathrm{~T} 2$ とも $70 \mathrm{~Gy}$ \\
1988 年 1 月以降 & $\mathrm{T} 1: 60 \mathrm{~Gy}$ (声門 $\mathrm{T} 1 \mathrm{~b}$, 声門上は $60 \mathrm{~Gy}$ か \\
& $70 \mathrm{~Gy})$ \\
& $\mathrm{T} 2: 70 \mathrm{~Gy}$ \\
1997 年 11 月以降 & 声門 $\mathrm{T} 1 \mathrm{a}: 60 \mathrm{~Gy}$ \\
& それ以外 : $66 \mathrm{~Gy} *$
\end{tabular}

備考

- 1991 年 9 月以降, 放射線治療前にレーザー手術を施行 - 1 回照射線量は $2 \mathrm{~Gy} 1$ 日 1 回, *のみ $1.2 \mathrm{~Gy} 1$ 日 2 回

\section{結 果}

放射線治療後に再発をきたしたのは 133 例中 20 例 (15 \%)であった。初回再発部位は，喉頭が 15 例（11\%）と， 再発例のなかでは $75 \%$ を占めており，これらはすべて初 回再発時には頸部リンパ節転移・遠隔転移を伴わなかっ た. 頸部リンパ節再発のみ認められたのは 4 例 (3\%) で あった。遠隔転移例は 1 例（1\%）であった。

発生部位別の頸部リンパ節再発例は声門 3 例，声門上 0 例，声門下 1 例であった（表 3 )。原発部位と頸部リン パ節転移の頻度に有意な関連はなかった（Yates 補正 $\chi^{2}$ 検定による).

臨床病期別の頸部リンパ節再発は I 期 3 例， II 期 1 例 であり，病期別の頻度はそれぞれ $3 \% ， 2 \%$ とほぼ同程度 であり, 病期が進むほど頻度が高くなることはなかった。

表 4 に症例を示す．頸部リンパ節再発例は 4 例とも男 性であり, 年齢は $55 \sim 75$ 歳, 平均 65 歳であった. 原発 巣は声門 T1a が 1 例（症例 1), 声門 T1b が 2 例（症例 $2 ， 3$ ，声門下 $\mathrm{T} 2$ が 1 例（症例 4）であった。原発巣に 前交連の病変を含む症例は 3 例あった。 初回治療終了後 から頸部リンパ節再発が確認されるまでの期間は 2 カ月 $\sim 4$ 年 7 カ (平均 2 年 0 カ月) であった. 頸部リンパ節 再発が確認された後に, 症例 4 を除く 3 例では全麻直達 喉頭鏡下に生検を行ったが癌病巣は認められなかった。
表 3 発生部位別の頸部リンパ節再発

\begin{tabular}{ccc}
\hline \hline 発生部位 & 症例数 & 䫇部リンパ節再発 \\
\hline 声門 & 112 & $3(3 \%)$ \\
声門上 & 17 & $0(0 \%)$ \\
声門下 & 4 & $1(25 \%)$
\end{tabular}

頸部リンパ節再発に対する治療は，全例頸部郭清を施 行しており，3 例は術後照射 $50 \mathrm{~Gy}$ を追加した．頸部郭 清の郭清範囲とリンパ節転移の部位と個数を表 5 に示し た. 声門下癌の症例 4 は下内深頸リンパ節に再発したが, 同時に前上縱隔にもリンパ節再発をきたしたため，同部 位の郭清と術後照射を行った。

症例 1 と症例 2 はその後局所再発が明らかになり，い ずれも喉頭全摘を行った。症例 1 は頸部郭清術後に左披 裂部の腫脹が持続し，次第に両声帯固定をきたした。そ の間，全麻直達喉頭鏡下の生検を計 3 回行ったが診断は つかず，頸部 CT でも喉頭に明らかな病変を認めず，喀 痰細胞診でクラスVであったため気管支鏡を施行したと ころ, 前交連下面に発赤を認め, その部位の擦過細胞診 より再発が明らかになった。頸部郭清術後 1 年 2 カ月で 喉摘となったが，再発病巣は喉頭を越え甲状腺にも浸潤 していた，術後さらに気管孔周囲に再発し死亡した。

症例 2 は頸部リンパ節再発に対する頸部郭清後 7 カ月 で右の披裂喉頭蓋ヒダに隆起性病変が生じ, 2 回目の生 検で再発と診断された。頸部郭清後 8カ月で手術となっ たが，粘膜下の進展が中咽頭まで及び，咽喉食摘を要し た。 その後両頸部に再発を繰り返しつつも手術や放射線・ 化学療法によってコントロールされ, 初回治療より 5 年 後の現在非担癌生存している.

症例 3 と症例 4 は頸部リンパ節再発に対する治療後は 喉頭を含め再発なく生存している。

\section{考按}

早期喉頭癌根治照射後, 局所再発を認めずに頸部リン パ節に再発をきたした場合，頸部リンパ節転移は初回治 療時，すでに存在していた可能性があるが，喉頭に小さ な残存病変があってそれが転移したといら可能性もあ る. 再発時にはこの両者は区別しがたいが，臨床経過よ り推測すると自験例の症例 1,2 は照射後から頸部リンパ 節再発までの期間がそれぞれ 4カ月，2力月と短いため， 初回治療時リンパ節腫大を疑わせる所見はなかったもの 
表 4 再発に対する治療と転帰

\begin{tabular}{|c|c|c|c|c|c|c|c|c|c|c|c|c|}
\hline 症例 & 年齢 & 亜部位 & $\mathrm{T}$ & 主病巣 & $\begin{array}{c}\text { 頸部再発まで } \\
\text { の期間 }\end{array}$ & $\begin{array}{c}\text { 再発後喉頭病変の } \\
\text { 除外 }\end{array}$ & 再発側 & $\begin{array}{c}\text { 頸部に対する } \\
\text { 治療 }\end{array}$ & $\begin{array}{l}\text { 合併病巣 / } \\
\text { 治療 }\end{array}$ & 再々発 & 喉頭 & 転帰 \\
\hline 1 & 60 & 声門 & $1 \mathrm{a}$ & 左声帯 & 4 カ月 & 直達喉頭鏡下生検 & 左 & $\begin{array}{l}\text { 左頸部郭清 } \rightarrow \\
\text { 術後 } 50 \mathrm{~Gy}\end{array}$ & なし & あり & 喉摘 & 現病死 \\
\hline 2 & 68 & 声門 & $1 b$ & 右声帯 & 2 力月 & 直達喉頭鏡下生検 & 右 & $\begin{array}{l}\text { 右頸部郭清 } \rightarrow \\
\text { 術 }\end{array}$ & なし & あり & 喉摘 & 生存 \\
\hline 3 & 75 & 声門 & $1 b$ & 左声帯 & 2 年 9 力月 & 直達喉頭鏡下生検 & 左 & 左頸部郭清 & なし & なし & 保存 & 生存 \\
\hline 4 & 55 & 声門下 & 2 & 声門下前方 & 4 年 7 力 & 喉頭ファイバー & 右 & $\begin{array}{l}\text { 右頸部郭清 } \rightarrow \\
\text { 術後 50Gy }\end{array}$ & $\begin{array}{c}\text { 前上縦隔 / } \\
\text { 同郭清 } \rightarrow 50 \mathrm{~Gy}\end{array}$ & なし & 保存 & 生存 \\
\hline
\end{tabular}

表 5 頸部郭清範囲とリンパ節転移の部位・個数

\begin{tabular}{|c|c|c|c|c|c|c|c|}
\hline 症例 & $\begin{array}{l}\text { 気管前· } \\
\text { 気管傍 }\end{array}$ & 顎下 & $\begin{array}{l}\text { 上内 } \\
\text { 深頸 }\end{array}$ & $\begin{array}{l}\text { 中内内 } \\
\text { 深頸 }\end{array}$ & $\begin{array}{l}\text { 下内 } \\
\text { 深頸 }\end{array}$ & $\begin{array}{l}\text { 鎖骨 } \\
\text { 上蓇 }\end{array}$ & 副神経 \\
\hline 1 & & & & 2 個 & & & 1 個 \\
\hline 2 & & & 1 個 & & & & X) \\
\hline 3 & & & 1 個 & & & & (1) \\
\hline 4 & & & & & \multicolumn{2}{|c|}{ 複数個癒合 } & \\
\hline
\end{tabular}

の不顕性のリンパ節転移があったと考えられる.

Fein $ら^{1)}$ は声門癌 T2N0 放射線治療例の報告ををとめ, 局所制御良好例に比べ局所制御不良例はリンパ節再発の 頻度が高いと述べている. 症例 1,2 は頸部リンパ節再発 の治療後に再々発して局所再発が明らかになった。 症例 1 は喉頭の再発病巣が直達喉頭鏡で観察が難しい前交連 直下にあり, 症例 2 は喉頭の再発病巣が粘膜下に進展し ており，いずれもみつかりにくい症例であったため，局 所再発より先に頸部リンパ節再発が発見されたと思われ る. やはり頸部リンパ節再発を認めたときには, 通常よ りも増して喉頭病変の有無に注意を払う必要があり, 喉 頭を観察する際には, 前交連下面, 後交連下面等死角に なりやすい部位に十分注意を払うべきである.

症例 3,4 は原発巣の再発が現れなかったことから, 局 所は照射によって制御されており，したがって初回治療 後に頸部リンパ節転移をきたしたとは考えにくい，する と, 症例 1,2 と同様初回治療時に不顕性の頸部リンパ節 転移があったことになるが, 症例 1,2 に比べ再発までの 期間が長いので, 腫瘍の増殖速度等何らかの生物学的性 質の差異があるものと思われる. 症例 4 は, 照射後 4 年 7カ月も経ってから頸部リンパ節再発をきたし, 㬋頭癌が 転移したにしては再発時期が遅すぎるため，他の部位に
重複癌が存在しておりそれが頸部リンパ節に転移した可 能性も考慮すべきであろう。しかしこの症例は, 再発に 対する頸部郭清後 9 年 6 力月経過観察を行っており, そ の間に他病変の出現を認めず, 他の部位に重複癌が存在 する可能性はほとんどないと考元られる。このように， 喉頭癌治療後 5 年近く経過し頸部リンパ節再発をきたす という再発の遅い症例もあることには注意が必要と思わ れる。

本邦の報告2) 11) では, 早期喉頭癌根治照射後の局所 再発を伴わない頸部リンパ節再発の頻度は1３\%であっ た (表 6). 自験例も $3 \%$ であり同様の結果であった.

局所再発を伴わない頸部リンパ節再発に対する治療と しては, 頸部郭清を行うという施設が多く2) 4)8)10111), な かには同時に喉摘を行ったという報告2)3) や, 照射のみ を行ったといら報告416) もある.これらの局所再発を伴わ ない頸部リンパ節再発例のうち, 治療と予後が明記され ている 11 例についてみてみると，7例（64\%）が予後良 好であったと報告されているが，頸部郭清を施行した 6 例のなかでは 5 例（83\%）が予後良好であったと報告さ れており, 頸部郭清を施行した症例の方が予後良好であ る傾向がみられた. また, Howell-Burke ら ${ }^{12)}$ は声門 T2N0 放射線治療例のうち頸部のみに再発した 3 例に対し頸部 郭清を行いコントロール良好であったと述べている.

自験例では 4 例とも臨床経過より, 局所再発巣がさら に頸部に転移をきたしたというよりは, 初回治療時に潜 在的であった頸部リンパ節転移が後から現れてきた可能 性が高いと推測された. I 期, II 期喉頭癌であっても, 不 顕性の頸部リンパ節転移の可能性があることに十分留意 して放射線治療後の経過観察を行うべきである. また， 4 例のうち2例は喉頭保存が可能であったことを考えると， 喉頭病変を認めない頸部リンパ節再発例に対して子防的 喉摘を行う必要はなく, 手術治療としては頸部郭清を施 
表 6 早期喉頭癌根治照射後の頸部リンパ節再発例

\begin{tabular}{lcccl}
\hline \hline \multicolumn{1}{c}{ 報告者 } & 報告年 & 症例数 & 頸部再発例 & \multicolumn{1}{c}{ 治療 } \\
\hline 玉虫 $^{2)}$ & 1983 & 78 & $1(1 \%)$ & 喉摘+頸部郭清 \\
古川ら $^{3)}$ & 1988 & 105 & $1(1 \%)$ & 喉摘+頸部郭清 \\
五十嵐ら $^{4)}$ & 1990 & 71 & $2(3 \%)$ & 頸部郭清+照射または照射のみ \\
林ら $^{5)}$ & 1991 & 73 & $1(1 \%)$ & $?$ \\
吉弘ら $^{6)}$ & 1994 & 36 & $1(3 \%)$ & 照射 \\
桑畑ら $^{7)}$ & 1995 & 69 & $1(1 \%)$ & 高齢のため行わず \\
盛川ら $^{8)}$ & 1995 & 48 & $1(2 \%)$ & 頸部郭清 \\
石川ら $^{9)}$ & 1997 & 30 & $1(3 \%)$ & ? \\
篠ら $^{10)}$ & 1997 & 70 & $1(1 \%)$ & 頸部郭清 \\
桜井ら $^{11)}$ & 2001 & 145 & $3(2 \%)$ & 頸部郭清
\end{tabular}

行するのが適当と思われた。

$$
\text { まとめ }
$$

早期喉頭癌根治照射後, 局所再発を認めない頸部リン パ節再発は 133 例中 4 例（3\%）に認められた. 頸部郭清 などの頸部に対する治療を行い，2 例は局所再発のため 喉頭保存できなかったが，2 例はその後再々発を認めな かった. 4 例とも臨床経過より, 初回治療時には潜在的 であった頸部リンパ節転移が後から現れてきた可能性が 高いと推測された。

本論文の要旨は第 14 回日本喉頭科学会（2002 年 3 月 22 日, 東京）にて報告した。

\section{参考文献}

1) Fein DA, Hanlon AL, Lee WR, et al. : Neck failure in T2N0 squamous cell carcinoma of the true vocal cords; the Fox Chase experience and review of the literature. Am J Clin Oncol $20: 154 \sim 157,1997$.

2）玉虫 昇, 西本喜版, 古川政樹, 他：当教室における 10 年 間の喉頭癌治療について。耳鼻 $29: 828 \sim 833 ， 1983$.

3）古川 滋，金子まどか，宮田佳代子，他：放射線治療を施 した早期㩔頭癌症例の検討. 耳鼻 $34: 397 \sim 403,1988$.

4）五十嵐文雄, 野々村直文, 中野雄一：当教室における喉頭
癌症例の検討，日耳鼻 $93: 772 \sim 778,1990$ 。

5）林 俊秀, 山際幹和, 坂倉康夫, 他 : 喉頭癌 147 例の臨床 統計. 耳鼻臨床 $84 ： 793 \sim 801,1991$.

6）吉弘 剛, 秋定 健, 林 玩己, 他：当教室における喉頭 癌の臨床的観察。耳鼻臨床 補 $69: 74 \sim 82,1994$.

7）桑畑直史, 鹿野真人, 大谷 镢：当科における喉頭癌の臨 床的検討. 耳鼻臨床 補 $83: 165 \sim 169,1995$.

8）盛川 宏, 佐藤道哉, 田部哲也, 他：喉頭癌の臨床統計的 観察. 耳鼻臨床 $88: 1161 \sim 1169,1995$.

9）石川和夫, 戸川 清, 宮崎総一郎, 他 : 喉頭癌 114 例の臨 床的検討. 耳鼻臨床 補 $94: 167 \sim 172,1997$.

10）篠 昭男, 吉原俊雄, 赤澤理恵子, 他 : 喉頭癌の臨床統計 的観察. 耳鼻臨床 $90: 703 \sim 709,1997$.

11）桜井一生, 宮城島正和, 加藤久幸, 他 : 喉頭癌放射線治療 後のリンパ節再発の検討.耳鼻 $47: 94 \sim 97,2001$.

12) Howell-Burke D, Peters LJ, Goepfert H, et al. : T2 glottic cancer; recurrence, salvage, and survival after definitive radiotherapy. Arch Otolarygol Head Neck Surg $116: 830 \sim 835$, 1990.

原稿受付：平成14年 4 月 16 日 原稿採択：平成14年 6 月 5 日 別刷請求先 : 楯谷智子 干524-0022 守山市守山5-4-30 滋賀県立成人病センター耳鼻咽喉科 